\title{
Article \\ Effect of Paper Sludge and Dendromass on Properties of Phytomass Pellets
}

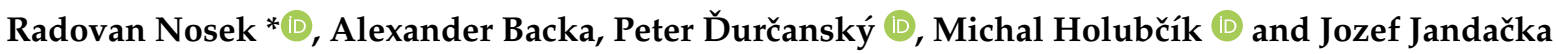 \\ Department of Power Engineering, Faculty of Mechanical Engineering, University of Žilina, Univerzitna 1, \\ 01026 Žilina, Slovakia; alexander.backa@fstroj.uniza.sk (A.B.); peter.durcansky@fstroj.uniza.sk (P.D..); \\ michal.holubcik@fstroj.uniza.sk (M.H.); jozef.jandacka@fstroj.uniza.sk (J.J.) \\ * Correspondence: radovan.nosek@fstroj.uniza.sk
}

Citation: Nosek, R.; Backa, A.; Ďurčanský, P.; Holubčík, M.; Jandačka, J. Effect of Paper Sludge and Dendromass on Properties of Phytomass Pellets. Appl. Sci. 2021, 11, 65. https://dx.doi.org/10.3390/ app11010065

Received: 7 December 2020 Accepted: 22 December 2020 Published: 23 December 2020

Publisher's Note: MDPI stays neutral with regard to jurisdictional claims in published maps and institutional affiliations.

Copyright: () 2020 by the authors. Licensee MDPI, Basel, Switzerland. This article is an open access article distributed under the terms and conditions of the Creative Commons Attribution (CC BY) license (https: / / creativecommons.org/ licenses/by/4.0/).

\begin{abstract}
Woody and agricultural wastes are important fuels in many countries, and have the potential of being even more important in the future. The main problems of plant biomass combustion are low ash melting temperatures and increased emissions. The most widely used treatment to solve the problem of low ash melting point is blending a fuel with an additive. In this work, pellets were produced from wheat straw containing wood sawdust and paper sludge in the following proportions 40:40:20 and 45:45:10 (straw/sawdust/paper sludge). The purpose of this work was to study the influence of sludge and dendromass on the straw pellet parameters and combustion process. The highest calorific value of $15.71 \mathrm{MJ} \mathrm{kg}^{-1}$ was registered for a sample with a $10 \%$ paper sludge concentration. The effectiveness of paper sludge was proved, and the ash melting temperature was increased from 1025 to $1328^{\circ} \mathrm{C}$ for the same sample.
\end{abstract}

Keywords: wheat straw; sawdust; paper sludge; combustion; emissions

\section{Introduction}

The European Union is working to move to clean energy, which means a decrease in the consumption of fossil fuels and an increase the proportion of renewable fuel energy sources. The issue of plant biomass, which is beginning to be used in larger quantities, is currently being addressed. Plant biomass can be processed into pellets or other forms for combustion purposes. Combustion of agricultural pellets brings with it various problems, and one of the most common is the low melting point of ash. The most important issue is the deformation temperature of the ash, i.e., when the ash starts to stick to the walls and parts of the boiler. After reaching the deformation temperature, the ash turns into slag, sinter, and other agglomerates. This means that combustion is influenced, and may even be stopped. The disadvantages of straw and other residues are also higher amounts of ash, and forming aggressive compounds during combustion. After reaching the deformation temperature, the ash turns into slag, sinter, and other agglomerates. These agglomerates inhibit the air supply to the base burning layer, such that the combustion process can be limited. This means that combustion is disrupted, and may even be stopped. Some of the ash particles are transferred by the flue gases and form deposits on the boiler walls. Higher emissions from the combustion of plant biomass containing undesirable compounds, compared to wood pellets, also cannot be ignored [1-4].

There are several ways to eliminate or reduce these disadvantages. One of the possibilities is to optimize the combustion device, or Co-combustion of plant biomass, with another fuel. Co-firing of wheat straw, pine stem wood, and softwood bark in a $150 \mathrm{~kW}$ boiler shows less signs of slagging and fouling propensities than combustion of pure straw. The proportion of plant biomass is given on the basis of the effect on the individual properties of the combustion process [5].

The co-firing of straw and natural gas has proved ineffective since the ash caused exposure to superheaters. The high flue gas temperature in the boiler was the reason for 
straw ash sticking on the walls. These problems are reduced by co-firing coal and straw because the coal contains sulfur, and ash adds $\mathrm{Al}$ and $\mathrm{Si}$. The ash and sulfur binds the alkali from the straw, inhibiting deposit formation and corrosion. It was determined that the concentration of sulfur resulted in a decrease of chlorine-induced corrosion in waste combustors. Based on calculations, the content of sulfur changes the melting point of the potassium compound to higher temperatures (from approximately 800 to $1100{ }^{\circ} \mathrm{C}$ ). The co-firing of straw and coal can be an effective method to utilize straw for power production [6-8]. The results of co-firing these fuels in a full-scale power plant indicated a decrease of $\mathrm{NO}$ and $\mathrm{SO}_{2}$ concentrations, and this was achieved by the addition of straw up to $20 \%$. The decrease in NO concentration was due to lower overall fuel-N conversion. The sulfur reduction was recorded with increasing straw proportion, and could be associated with the high potassium concentration of straw [9].

Improving the properties of plant biomass can be also achieved by adding various additives that increase the melting temperature of ash. Additives have various chemical compositions, and in the work of Wang et al. the ash related issues of briquettes were mitigated with phosphorus-based additives. Maize straw briquettes with the addition of ammonium dihydrogen phosphate and calcium phosphate monobasic significantly inhibited ash slagging and melting problems [10]. The influence of kaolin and dolomite as additives to the different straws was also investigated. These additives were added to rape, wheat, and barley straw ashes at $550{ }^{\circ} \mathrm{C}$, and the results showed that the low melting points of the straws could be enhanced by kaolin and dolomite [11]. The tests of ashes from mixtures of rye straw and three additives were done at the same conditions. The addition of kaolin substantially increased the sintering and melting temperatures of the rye straw ash. The test with calcite showed the best results in abating the sintering, and the addition of Ca-sludge was less pronounced in terms of sintering decrease [12].

Paper sludge is generated as waste in the paper industry. Due to its low calorific value, the sludge itself is not interesting for energy use. The high concentration of calcite and kaolin in paper sludge makes it an attractive additive. [13]. These minerals showed a decrease of slagging and increase of melting temperature during the combustion of biomass pellets [14-16].

Plant biomass would appear to offer no benefits over dendromass. Its main advantage is the low price compared to other fuels, availability near the place of use, and thus a reduction in the total costs associated with transport, and therefore it is important to find the parameters for optimal combustion $[13,17]$.

The aim of this work was to increase the melting temperature of ash by producing pellets with content of sawdust and paper sludge as an additive. The goal was to experimentally achieve the optimal ratio of these three raw materials, where the combustion process would proceed correctly without the mentioned issues, and with respect to a low emissions concentration.

\section{Materials and Methods}

In this work, wheat straw and sawdust, both with average measured moisture around $4 \%$, were used as input material. Paper sludge with a moisture content of $25 \%$ was used as an additive. Paper sludge ash has a fluid temperature above $1500{ }^{\circ} \mathrm{C}$, and this can be explained by its high calcium and silica content [18-20]. For the production of quality pellets, moisture content of about $4 \%$ of the input material was needed. Therefore, it was necessary to dry the paper sludge in a MEMMERT dryer with forced ventilation until an average moisture of about $3-5 \%$ was reached. The pelleting of input ingredients was done in a pellet press, KAHL 33-390/500. The four pellet samples were produced with the following contents: $100 \%$ of wheat straw (S-100), $100 \%$ of sawdust (SD-100), $45 \%$ straw $/ 45 \%$ sawdust $/ 10 \%$ paper sludge (SSPS- $45 / 45 / 10$ ), and $40 \%$ straw $/ 40 \%$ sawdust $/ 20 \%$ paper sludge (SSPS-40/40/20). 
Figure 1 shows the produced samples of pellets, and at first glance the color differences of the samples are obvious, where the increasing proportion of sludge has a darkening effect on the samples.

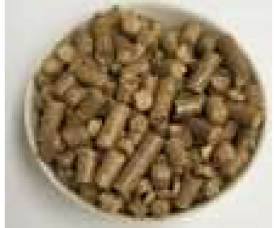

(a)

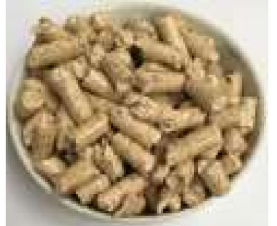

(b)

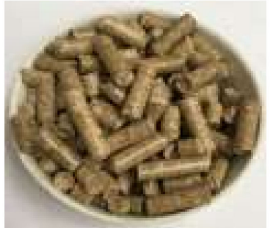

(c)

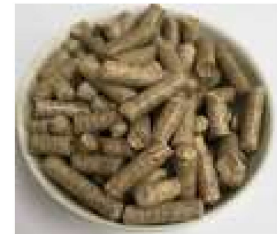

(d)

Figure 1. Samples of pellets: (a) S-100 (b) SD-100 (c) SSPS-45/45/10 (d) SSPS-40/40/20.

\subsection{Ultimate and Proximate Analysis of Samples}

The produced samples were analyzed in CHN628 and TGA-701 analyzers, LECO. Figure 2 presents the ultimate analysis of the fuels, and a decrease in the $\mathrm{C}$ and $\mathrm{H}$ content of the samples with the concentration of paper sludge was registered compare to the SD-100 sample.

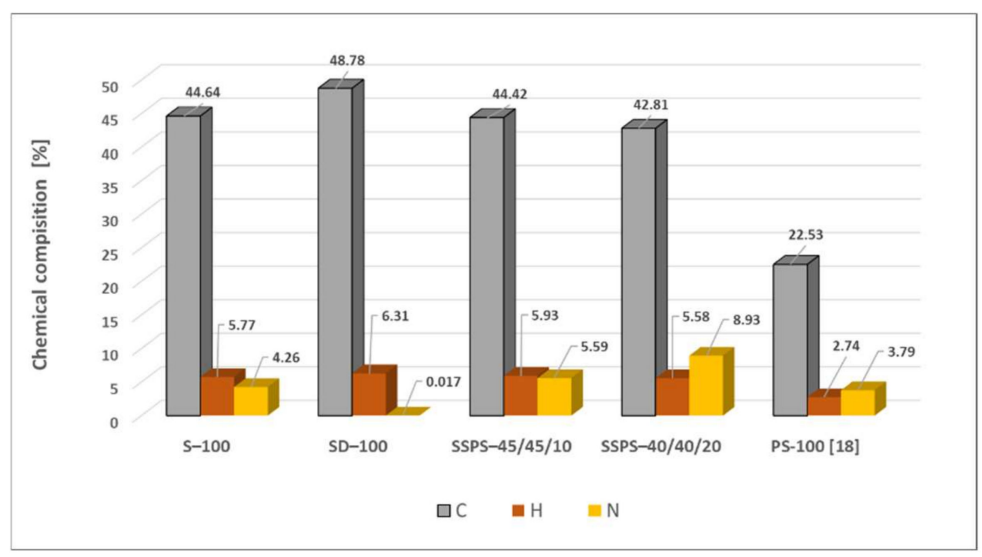

Figure 2. Ultimate analysis of pellet samples compared to paper sludge pellets (PS100).

There was an increased proportion of nitrogen in the samples except the pellets made of sawdust. The content of $\mathrm{N}$ was relatively high in sample S-100 due to excessive soil fertilization. The sample made of paper sludge also had a higher concentration of nitrogen, and influenced the samples SSPS $-45 / 45 / 10$ and SSPS $-40 / 40 / 20$. The standard deviation of analyzed carbon and nitrogen was in the range of $\pm 0.5 \%$, and in the case of hydrogen the fluctuation was $\pm 0.8 \%$.

\subsection{Analysis of Samples}

The proximate analysis of the samples was performed on a thermogravimetric analyzer TGA 701. The results of the measured moisture, volatile matter, ash, and fixed carbon are presented in Table 1.

Table 1. Proximate analysis of samples.

\begin{tabular}{ccccc}
\hline Sample & Moisture (\%) & Volatile Matter (\%) & Ash (\%) & Fixed Carbon (\%) \\
\hline S-100 & 6.87 & 71.30 & 5.02 & 16.81 \\
SD-100 & 3.86 & 74.99 & 0.49 & 16.31 \\
SSPS-45/45/10 & 5.83 & 70.90 & 6.8 & 16.47 \\
SSPS-40/40/20 & 4.13 & 70.27 & 10.53 & 15.07 \\
PS100 [18] & 5.61 & 55.71 & 42 & 0.93 \\
Standard deviation & \pm 1.24 & \pm 0.78 & \pm 2.53 & \pm 1.08 \\
\hline
\end{tabular}


It can be noticed that sample SSPS $45 / 45 / 10$ shows a similar concentration as the pellets made of pure straw. The highest value of ash was measured for the sample SSPS $40 / 40 / 20$. For comparison, the paper sludge (PS100) contains a high ash concentration, and it is almost 100 times higher than that of SD-100.

\subsection{Calorific Values}

A LECO AC 500 calorimeter was used to determine the higher calorific value (HCV) of samples, and the lower calorific values $(L C V)$ were subsequently calculated by the following equation [21]:

$$
L C V=H C V-\mathrm{r}_{H 2 O}\left(W_{p}+8.94 \cdot x_{H}\right)
$$

where $\mathrm{r}_{\mathrm{H} 2 \mathrm{O}}$ is the water heat of vaporization $[\mathrm{kJ} / \mathrm{kg}], W_{p}$ is water content in the sample (\% wt.), 8.94 hydrogen to water conversion coefficient and $x_{H}=0.01 \cdot H_{h} \cdot B_{p}$; where $H_{h}$ is the hydrogen content in the sample (\% wt.), $B_{p}$ is volatile content in the sample (\% wt.).

The highest $L C V$ was found for the pure wood pellets $\left(16.82 \mathrm{MJ} \cdot \mathrm{kg}^{-1}\right)$, and the sample of pure straw reached the lower calorific value of up to $16.46 \mathrm{MJ} \cdot \mathrm{kg}^{-1}$. The calorific value of paper sludge was $4.33 \mathrm{MJ} \mathrm{kg}^{-1}$ [18]. The higher the percentage of sludge content in the pellets, the lower the calorific value of the fuel, which is due to the low calorific value of the paper sludge itself (Figure 3).

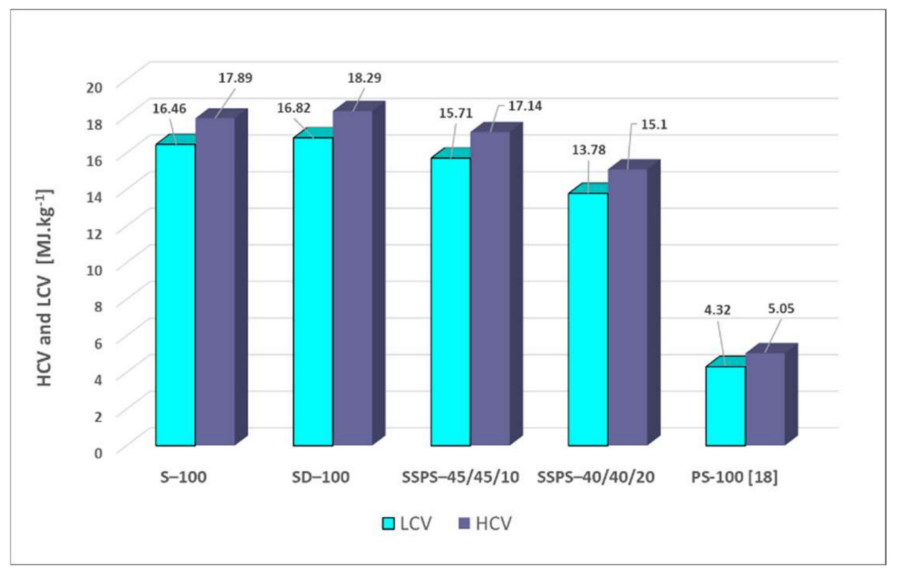

Figure 3. Calorific values of the pellet samples.

\subsection{The Ash Melting Temperatures of Samples}

Ash fusion temperatures are crucial quality parameters for predicting the performance of a fuel, and analyze the tendency for slagging. The ash melting points of the samples were measured on the basis of the STN ISO 540 standard. The meltability of ash was analyzed by a LECO AF 700 device, monitoring the deformation of ash pyramids at different temperatures. The characteristic changes of ash melting are defined by the following temperatures: DT—deformation temperature, ST—-shrinkage (softening) temperature, HT—hemisphere temperature, and FT-flow (fluid) temperature.

In Table 2 are presented the ash melting points of the produced samples, and the measured results indicated that a higher concentration of sludge raised the ash melting temperatures. The highest ash deformation temperature was recorded for the sample SSPS $-45 / 45 / 10$, and such a value would be expected for a sample with a $20 \%$ sludge concentration. The resulting anomaly is probably because the ash was not homogeneous, and could have contained less sludge due to uneven mixing. 
Table 2. Melting temperatures of the pellet samples.

\begin{tabular}{ccccc}
\hline Sample & DT $\left({ }^{\circ} \mathbf{C}\right)$ & ST $\left({ }^{\circ} \mathbf{C}\right)$ & HT $\left({ }^{\circ} \mathbf{C}\right)$ & FT $\left({ }^{\circ} \mathbf{C}\right)$ \\
\hline S100 & 1025 & 1081 & 1121 & 1205 \\
SD-100 & 1115 & 1254 & 1313 & 1500 \\
SSPS-45/45/10 & 1328 & $>1500$ & $>1500$ & $>1500$ \\
SSPS-40/40/20 & 1301 & $>1500$ & $>1500$ & $>1500$ \\
PS100 [18] & 1305 & $>1500$ & $>1500$ & $>1500$ \\
Standard deviation & \pm 0.23 & \pm 0.15 & \pm 0.13 & \pm 0.08 \\
\hline
\end{tabular}

\section{Experimental Research and Results}

3.1. Experimental Combustion in the Boiler

Combustion of the samples was performed in an experimental boiler with a rated heat output of $18 \mathrm{~kW}$ (Figure 4). The emission probes and thermocouples were installed into the chimney, and a data logger registered all parameters.

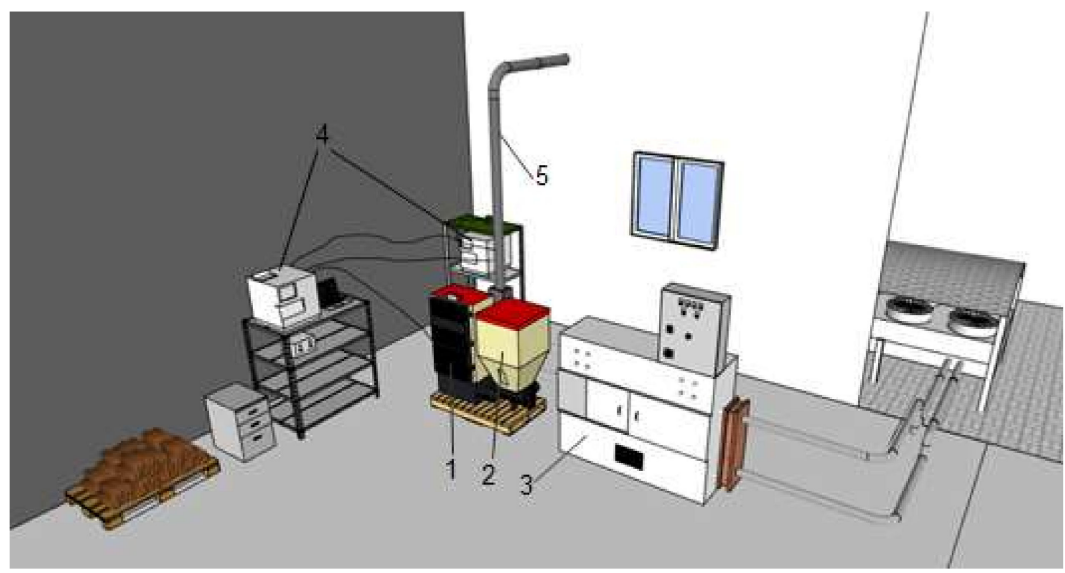

Figure 4. Experimental setup: 1-pellet boiler, 2-fuel tank, 3-heat exchanger station, 4-flue gas analyzers and data logger, 5-chimney.

Combustion of all pellet samples was carried out at the same operating conditions, and three measurements for each sample were performed. Approximately $6.5 \mathrm{~kg}$ of pellets were burned during one measurement, which lasted $60 \mathrm{~min}$.

\subsection{The Analyses of Results}

The experimental measurements consisted of two tasks, in the first the boiler heat power was recorded, and in the second the concentrations of gaseous emissions and particulate matter $(\mathrm{PM})$ were measured.

The heat power of the boiler did not differ significantly during all three measurements of one sample, since the boiler operated under stable conditions. Figure 5 shows the average power values of the boiler, and the highest power was registered when burning a sample of $100 \%$ pure wood pellets. A slightly lower power of $11.82 \mathrm{~kW}$ was measured for the sample SSPS-45/45/10, but it was higher by more than $2 \mathrm{~kW}$ compare to pure straw. The lowest heat output of the boiler was $9.49 \mathrm{~kW}$, which was caused by a $20 \%$ share of paper sludge in the sample SSPS-40/40/20. The standard deviation of the measured values was evaluated, and was in the range of $0.49-1.10 \mathrm{~kW}$ (see Figure 5). 


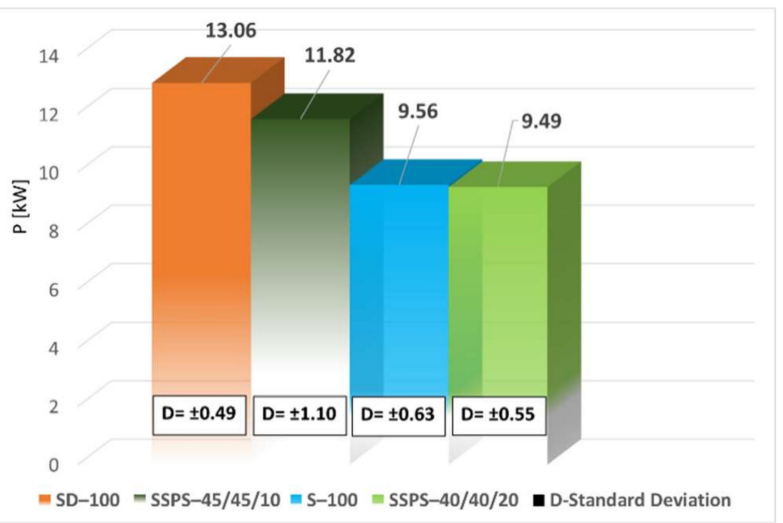

Figure 5. Comparison of the average heat output of the boiler.

In Figure 6a are the average values of carbon monoxide emissions measured during the combustion of the four pellet samples. The $\mathrm{CO}$ is formed during the incomplete combustion as a by-product, and its concentration depends on the amount of oxygen supplied to the combustion process. According to the standard STN EN 303-5 2012, the maximum CO concentration is $3000 \mathrm{mg} \cdot \mathrm{m}^{-3}$ for an automatic boiler with a rated heat power up to $50 \mathrm{~kW}$. All the produced samples met this standard, and the sample SD-100 had the lowest concentration of $\mathrm{CO}$, as expected.

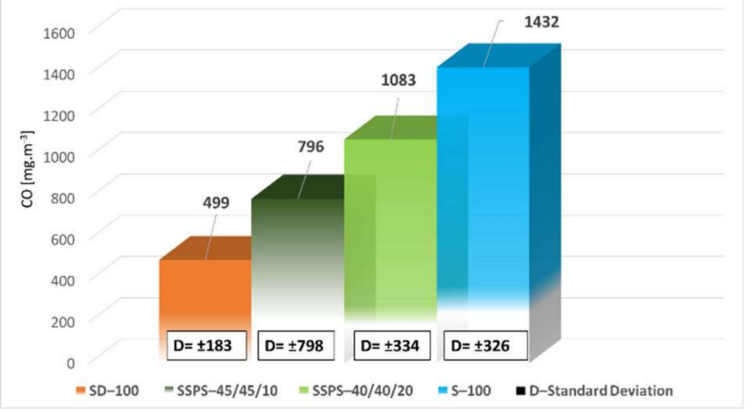

(a)

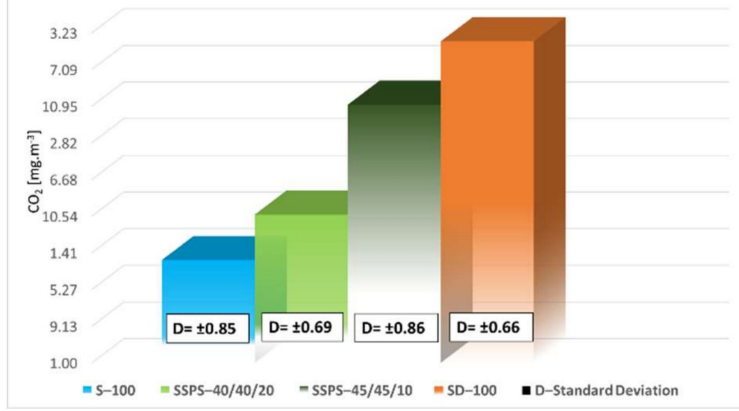

(b)

Figure 6. (a) Comparison of the average $\mathrm{CO}$ emissions, and (b) comparison of average $\mathrm{CO}_{2}$ emissions.

The highest $\mathrm{CO}_{2}$ emissions were during the combustion of 100-SD, indicating complete combustion. Thus, most of the $\mathrm{C}$ contained in this sample had left the boiler in the form of $\mathrm{CO}_{2}$. The results of sample S-100 showed the lowest concentration, as expected.

Another monitored emission parameter was NOx, which is formed depending on high temperatures by nitrogen oxidation, and chemical composition of the fuel. The value of the NOx emission limit for the combustion of phytomass is at the level of $650 \mathrm{mg} \cdot \mathrm{m}^{-3}$. This value was met by all the tested pellet samples. In Figure 7a it can be seen that the lowest NOx emission production was shown for a sample of pure wood pellets of $179 \mathrm{mg} \cdot \mathrm{m}^{-3}$, followed by a sample of pure straw of $295 \mathrm{mg} \cdot \mathrm{m}^{-3}$. The SSPS $-45 / 45 / 10$ and 40/40/20 samples reached approximately the same NOx values, of $330 \mathrm{mg} \cdot \mathrm{m}^{-3}$.

It is also important to control the concentration of particulate matters, mainly due to the inhalation of these particles and the harmful effect on the human body [15]. The concentrations of the total particulate matters measured for the produced samples can be seen in Figure 7b. It is clear from the results that the SD-100 sample produced the least amount of PM, and the highest amounts of PM were measured for pellets made from pure straw. According to the standard STN EN 303-5 2012, a limit of up to $150 \mathrm{mg} \cdot \mathrm{m}^{-3}$ is set for particulate matters. 


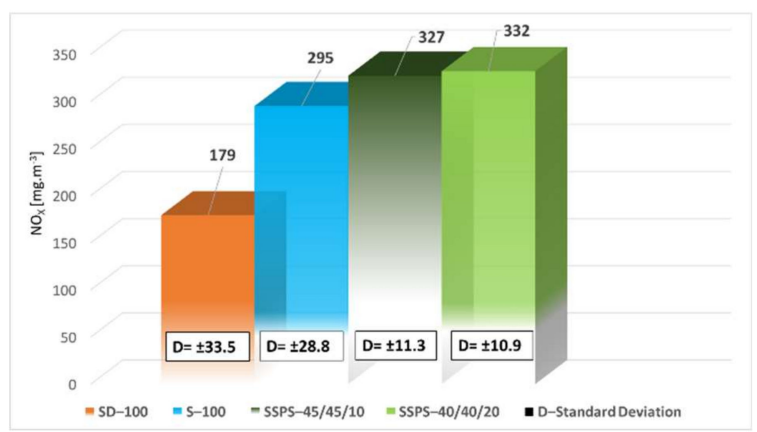

(a)

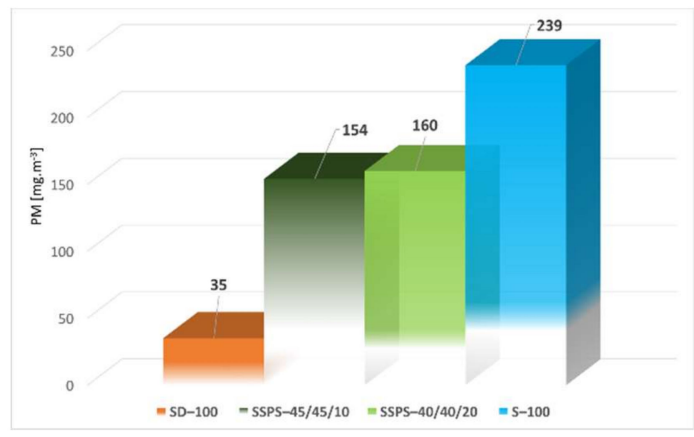

(b)

Figure 7. (a) Comparison of average $\mathrm{NO}_{X}$ emissions, and (b) comparison of average particulate matters (PM).

\section{Discussion and Conclusions}

Many manufacturers are looking for solutions to prevent the problem of the low ash melting temperatures of plant biomass. They try to solve this by modifying parts of the combustion device (e.g., burner) or by producing pellets with admixtures of various raw materials and additives that would suppress these undesirable properties. The increase of ash melting temperature was already investigated in a previous work, and data showed that $10 \%$ of sludge raised the temperature to around $250{ }^{\circ} \mathrm{C}$ [18].

This work was focused on the production of pellets from straw, wood sawdust, and paper sludge, which would contribute to the improvement of some properties compared to pure straw. A total of three independent measurements were performed for each sample of pellets under steady-state conditions. The sample SSPS $45 / 45 / 10$ seem to be a promising option in terms of the examined parameters. Boiler heat output boiler during the combustion of this sample was higher in comparison to the pure straw sample, and the concentration of $\mathrm{CO}$ emissions was half as low compared to the $\mathrm{S}-100$ sample. The measured NOx emissions for SSPS-45/45/10 were slightly higher (around 10\%) compared to pure straw. In the case of $\mathrm{CO}_{2}$ the difference between all of the samples was negligible. The PM concentration measured for the SSPS $45 / 45 / 10$ sample was $154 \mathrm{mg} \cdot \mathrm{m}^{-3}$, and this is approximately $35.6 \%$ less than S-100. The positive properties of the paper sludge were verified in its ability to raise the melting temperature of the plant biomass ash. After addition of $10 \%$ sludge, an increase of deformation temperature from 1025 to $1328^{\circ} \mathrm{C}$ was noticed compared to the reference pellet. The combustion of the samples confirmed the possibility of seamless operation of the boiler.

Co-firing of straw, saw dust, and a small amount of paper sludge (about $10 \%$ ) in the form of pellets can be an effective way to utilize straw in thermal energy production. The combination of these materials should be experimentally measured in a full-scale power plant to verify the results.

Author Contributions: R.N.; experimental methodology, investigation, data collection, writingoriginal draft, A.B. and P.D.; preparation of the testing equipment, formal analysis, M.H.; analysis of the data and validation, J.J.; writing and editing. All authors have read and agreed to the published version of the manuscript.

Funding: This research was funded by KEGA No. 038ŽU-4/2019 Piping systems in heat supply and VEGA No. 1/0479/19 "Influence of combustion conditions on production of solid pollutants in small heat sources".

Institutional Review Board Statement: Not applicable.

Informed Consent Statement: Not applicable.

Data Availability Statement: Data available in a publicly accessible repository.

Conflicts of Interest: The funders had no role in the design of the study; in the collection, analyses, or interpretation of data; in the writing of the manuscript, or in the decision to publish the results. 


\section{References}

1. Van Loo, S.; Koppejan, J. The Handbook of Biomass Combustion and CO-Firing, 1st ed.; Routledge: London, UK, 2008; ISBN 978-1849711043.

2. Fournel, S.; Palacios, J.H.; Godbout, S.; Heitz, M. Effect of additives and fuel blending on emissions and ash-related problems from small-scale combustion of reed canary grass. Agriculture 2015, 5, 561-576. [CrossRef]

3. Wang, L.; Hustad, J.E.; Skreiberg, Ø.; Skjevrak, G.; Grønli, M. A Critical Review on Additives to Reduce Ash Related Operation Problems in Biomass Combustion Applications. Energy Procedia 2012, 20, 20-29. [CrossRef]

4. Steenari, B.M.; Lundberg, A.; Pettersson, H.; Wilewska-Bien, M.; Andersson, D. Investigation of ash sintering during combustion of agricultural residues and the effect of additives. Energy Fuels 2009, 23, 5655-5662. [CrossRef]

5. Nordgren, D.; Hedman, H.; Padban, N.; Boström, D.; Öhman, M. Ash transformations in pulverised fuel co-combustion of straw and woody biomass. Fuel Process. Technol. 2013, 105, 52-58. [CrossRef]

6. Overgaard, P.; Larsen, E.; Fribord, K.; Hille, T.; Jensen, P.A.; Kaer, S.K. Full-Scale Tests on Co-Firing of Straw in a Natural GasFired Boiler. 2005. Available online: http:/ / citeseerx.ist.psu.edu/viewdoc/download?doi=10.1.1.561.1803\&rep=rep1\&type=pdf (accessed on 30 March 2018).

7. Leckner, B. Co-combustion-A summary of technology. Therm. Sci. 2007, 11, 5-40. [CrossRef]

8. Krause, H.H. High-Temperature Corrosion Problems in Waste Incineration Systems. J. Mater. Energy Syst. 1986, 7, 322-332. [CrossRef]

9. $\quad$ Pedersen, L.S.; Nielsen, H.P.; Kiil, S.; Hansen, L.A.; Dam-Johansen, K.; Kildsig, F.; Christensen, J.; Jespersen, P. Full-scale co-firing of straw and coal. Fuel 1996, 75, 1584-1590. [CrossRef]

10. Wang, Q.; Han, K.; Wang, J.; Gao, J.; Lu, C. Influence of phosphorous based additives on ash melting characteristics during combustion of biomass briquette fuel. Renew. Energy 2017, 113, 428-437. [CrossRef]

11. Steenari, B.M.; Lindqvist, O. High temperature reactions of straw ash and the anti-sintering additives kaolin and dolomite. Biomass Bioenergy 1998, 14, 67-76. [CrossRef]

12. Wang, L.; Skreiberg, O.; Becidan, M.; Li, H. Investigation of rye straw ash sintering characteristics and the effect of additives. Appl. Energy 2016, 162, 1195-1204. [CrossRef]

13. Matúš, M.; Križan, P.; Šooš, L.; Beniak, J. The effect of papermaking sludge as an additive to biomass pellets on the final quality of the fuel. Fuel 2018, 219, 196-204. [CrossRef]

14. Öhman, M.; Gilbe, R.; Lindstrom, E.; Bostrom, D. Slagging characteristics during residential combustion of biomass pellets. In Proceedings of the 2nd World Conference on Pellets in Jönköping, Jönköping, Sweden, 30 May-1 June 2006; Swedish Bioenergy Association: Stockholm, Sweden, 2006; pp. 93-100.

15. Wang, L.; Skjevrak, G.; Hustad, J.E.; Grønli, M.G.; Skreiberg, O. Effects of additives on barley straw and husk ashes sintering characteristics. Energy Procedia 2012, 20, 30-39. [CrossRef]

16. Ondruska, J.; Čačko, V.; Biath, P. Energy recovery of solid noble biofuels from phytomass. In Energy from Biomass (in Czech Language); VUT v Brně: Antonínská, Brno, Czech Republic, 2012; ISBN 978-80-214-4685-4.

17. Čaja, A.; Papučík, Š.; Patsch, M.; Kantová, N. The Visualization of Combustion Air Flow that Flows into the Dendromass Combustion Process Using CFD Simulations. Renew. Energy Sources Eng. Technol. Innov. 2018, 25-31. [CrossRef]

18. Nosek, R.; Werle, S.; Borsukiewicz, A.; Żelazna, A.; Łagód, G. Investigation of pellet properties produced from a mix of straw and paper sludge. Appl. Sci. 2020, 10, 5450. [CrossRef]

19. Vamvuka, D.; Kakaras, E. Ash properties and environmental impact of various biomass and coal fuels and their blends. Fuel Process. Technol. 2011, 92, 570-581. [CrossRef]

20. Tun, M.M.; Juchelková, D.; Raclavská, H.; Sassmanová, V. Utilization of biodegradable wastes as a clean energy source in the developing countries: A case study in Myanmar. Energies 2018, 11, 3183.

21. Palacka, M.; Vician, P.; Holubčík, M.; Jandačka, J. The energy characteristics of different parts of the tree. Procedia Eng. 2017, 192, 654-658. [CrossRef] 